\title{
Special issue on the contributions of James Buchanan
}

This issue of Constitutional Political Economy focuses on the work of James M. Buchanan, who died last January after a short illness at the age of 93.

A special memorial conference on his work was held at George Mason University in September of 2013, at which a series of distinguished scholars presented papers on Buchanan's research and its influence on constitutional theory, law and economics, experimental economics, and political philosophy. A subset of the papers presented at the conference appear in this volume. Others will appear later this year, and one other has already been published in a previous issue. The papers are not paeans to Buchanan, but scholarly summaries and assessments of his contributions.

It is especially appropriate that this overview of Buchanan's contributions to constitutional political economy be published in this journal, because it was at his encouragement that Viktor Vanberg and Richard Wagner founded the journal some 20 years ago. 